\title{
Vitae
}

33 (2018) 445-461

Ks. Janusz Królikowski

Uniwersytet Papieski Jana Pawła II, Kraków

jkroliko@poczta.onet.pl, ORCID: 0000-0003-3929-6008

\section{CZY GNIEW ZAWSZE JEST GRZECHEM?}

Is Wrath Always a Sin?

STRESZCZENIE

Zagadnienie gniewu, którym od wielu wieków zajmuje się refleksja filozoficzna i teologiczna, stanowi jeden z bardzo ważnych tematów moralnych. Już filozofia starożytna dokonała jego opisu, a w oparciu o niego zawsze potępia gniew jako jedną z wyjątkowo destrukcyjnych wad duchowych. Tradycja chrześcijańska, przyjmując takie ujęcie, bardzo wcześnie postawiła pytanie, czy taka jednostronna odpowiedź jest wystarczająca. Przecież także Bóg gniewa się: Chrystus rozgniewał się na kupców świątyni i z gniewem dokona osądu człowieka oraz świata. Już św. Grzegorz Wielki wyraźnie stwierdził, że gniew w słusznej sprawie może być wyrazem gorliwości. Św. Tomasz z Akwinu, w kontekście tradycji średniowiecznej, która wiele uwagi poświeciła wadom głównym, spójnie wykazał, że może istnieć gniew godziwy, a w niektórych wypadkach odgrywa
SŁOWA KLUCZE

wady główne; gniew; grzech; cnota 
on wprost niezastąpioną rolę, a więc jest możliwy nawet „święty gniew”.

Abstract

The question of wrath constitutes an essential problem which for centuries has found its place at the centre of philosophical and theological reflection. Wrath has been described as one of the most destructive of spiritual vices. Assuming this point of view, Christian tradition posed a question long ago as to whether such a unilateral answer is sufficient. Consider that even God is sometimes wrathful, that Christ focused his wrath on the merchants in the temple, and that man and the world will suffer His wrath on the day of judgment. Saint Gregory the Great stated explicitly that wrath, used in a just cause, may be a manifestation of zeal. Saint Thomas Aquinas, in the context of medieval tradition, which devoted a lot of attention to capital vices, demonstrated coherently that wrath can be decent, and in some cases plays an irreplaceable role. Therefore, even a "holy wrath" is possible.
KEYWORDS

cardinal vices;

wrath; sin; virtue

Refleksja filozoficzna i teologiczna nad gniewem ma bardzo długie dzieje. Rodząc się i rozwijając najpierw w starożytnym świecie greckim, a potem łacińskim, zyskała ona wyjątkowo na znaczeniu, okrzepła w swojej systematyczności, a w końcu nabrała niemal paradygmatycznego znaczenia $\mathrm{w}$ stosunku do szerszego zagadnienia relacji między pasjami ${ }^{1}$

1 W tekście będziemy odwoływać się do pojęcia "pasji”, a nie do pojęcia „namiętności”, jak na ogół tłumaczy się łacińskie passio. Słowo 
i rozumem ${ }^{2}$, które posiadają podstawowe znaczenie w etyce i duchowości. Problem pozostaje aktualny, ponieważ wiele ludzkich doświadczeń nosi negatywnie widziane znamiona gniewu, a w niejednym przypadku - na odwrót - pojawiają się propozycje reakcji na niektóre zjawiska właśnie za pośrednictwem gniewu. Mamy więc do czynienia w czymś w rodzaju „dialektyki gniewu”: z jednej strony jest on widziany jako wada główna, która przeradza się w grzech potępiany zarówno przez tradycję biblijną, jak i przez chrześcijańską tradycję duchową oraz moralną, ale z drugiej strony jest ewidentne, że nawet Bóg, w którego wierzymy, jest Bogiem, który się gniewa, a wskazania duchowe nie wahają się proponować w niektórych sytuacjach potrzebę przyjęcia postawy „świętego gniewu”. Czy da się pogodzić tę sprzeczność? Jak gniewać się, nie grzesząc równocześnie? Czy jest możliwe spójne traktowanie tej dialektyki, czyniąc z niej element doświadczenia chrześcijańskiego?

\section{Z DZIEJÓW REFLEKSJI NAD GNIEWEM}

W świecie homeryckim gniew reprezentował wyjątkową wartość, wskazując na obecność w człowieku gniewliwym rysów heroizmu i szlachetności. W refleksji filozoficznej Platona, Arystotelesa i stoików gniew jest traktowany jako pasja. Jak każda pasja został usytuowany w irracjonalnej sferze duszy, a tym samym nabrał zarazem negatywnego znaczenia, czyli został uznany za wadę, stając się przejawem degradacji i patologii. Gniew, podobnie jak inne pasje, stał się „chorobą duszy” i w tym procesie stopniowego ukierunkowania antropologii i psychologii na opracowanie wskazań

"namiętność” w języku polskim posiada konotacje etyczne, dlatego lepiej posługiwać się bardziej neutralnym z etycznego punktu widzenia słowem "pasja/pasje”.

2 Por. Veghetti, „Passioni antiche”, 39-73. 
i zaproponowanie działań leczących otrzymał wnikliwy opis, którego dokonali zwłaszcza stoicy.

Traktat De ira Seneki stanowi klasyczny punkt odniesienia zarówno dla refleksji filozoficznej, jak i dla teologii chrześcijańskiej, zarówno patrystycznej, jak i scholastycznej. Seneka, za którym poszła tradycja chrześcijańska, podkreślił, że gniew powoduje niedopuszczalną degradację człowieka. Napisał więc na początku swego traktatu:

„Niektórzy z mędrców nazwali gniew krótkotrwałym szaleństwem. W równej bowiem mierze, jak ono, gniew nie panuje nad sobą, zapomina o przyzwoitości, nie pamięta o związkach przyjaźni i pokrewieństwa, z uporem i natężeniem dąży do wykonania tego, co rozpoczął, jest niedostępny dla rozsądku i wszelkiej perswazji, wybucha $\mathrm{z}$ błahych powodów, jest niezdolny do rozróżnienia słuszności i prawdy, a przy tym jest do złudzenia podobny do walących się gmachów, które rozsypują się w gruzy na wierzchu tego, co przytłoczyły swoim ciężarem”3.

Ta rozbudowana uwaga Seneki została przyjęta przez Marcina z Bragi w jego traktacie De ira, w którym pokazał dalsze degradujące skutki tej pasji:

„Gniew przemienia najlepszą i najsłuszniejszą rzecz w jej przeciwieństwo. Wszyscy ci, którzy są nim owładnięci, nie są w stanie pamiętać o swoich obowiązkach; ulegający gniewowi syn staje się ojcobójcą, matka macochą, król tyranem. Gniew nie jest użyteczny nawet $w$ walce, ponieważ pozbawia rozwagi; całkowicie zdominowany pragnieniem uderzenia innych, nie chroni przed niebezpieczeństwem, kończąc poddaniem się innym”“ .

Ze stanowiskiem zajętym przez filozofię grecką i łacińską kontrastuje wyraźnie głęboka dwuznaczność, z jaką temat

3 Seneca, De ira, 1, 2 (Seneka, Pisma filozoficzne, I, 244-245).

4 Marcin z Bragi, De ira, 1 (Mediaevalia, 144). 
gniewu jest ujmowany w najpierw w tradycji żydowskiej, a potem także chrześcijańskiej'. Nie ulega wątpliwości, że Nowy Testament widzi w Chrystusie wzór cichości i łagodności (Mt 11,29) oraz piętnuje wszelkie dążenie do zemsty. Jest jednak tak samo prawdą, że w Biblii, łącznie z Ewangeliami, można spotkać wypowiedzi całkowicie przeciwne. Idea zagniewanego i strasznego Boga mściciela, którym jest Bóg Abrahama, Izaaka i Jakuba, jest właściwie obecna w całym Starym Testamencie, nawet jeśli niekiedy wywołuje zgorszenie. Jakże mocno rozbrzmiewa ona choćby w Psalmie 94: „Boże, Mścicielu, Panie, Boże, Mścicielu, ukaż się!” (94,1). Gniew Boga jest widziany jako coś najbardziej słusznego, jako manifestacja Jego świętości i sprawiedliwości, a odwoływanie się do niego w modlitwie jest traktowane jako coś zwyczajnego, jako manifestacja sprawiedliwości moralnej ${ }^{6}$. Ta wizja religijna ma także odniesienie do postawy człowieka. Bardzo sugestywnie brzmią słowa Psalmu: „Gniewajcie się, a nie grzeszcie [Irascimini, et nolite peccare]" $(4,5)^{7}$, które zdają się jakoś legitymizować gniew. Przede wszystkim jednak obraz zagniewanego Jezusa, niejako kwestionującego swoją zwyczajną łagodność, gdy wyrzuca kupców ze świątyni ${ }^{8}$, otwiera problem egzegetyczny, który poszerza problematykę filozoficzno-teologiczną. Czy jest więc możliwe, aby Chrystus, który jest wzorem wszelkiej doskonałości, był rzeczywiście zagniewany? Czy można wiecznemu Synowi Bożemu przypisać pasje należące do natury człowieka? Obraz okazjonalnego gniewu Chrystusa wobec poważnych wykroczeń, których nie można tolerować, odsyła do drastycznej sceny sądu ostatecznego, zdominowanej przez gniew Boży, czyli słuszną zemstę sprawiedliwego Sędziego w stosunku do

5 Por. Léon-Dufour, „Gniew”, 286-293.

6 Por. Cazelles, La Bible, 100-102.

7 Biblia Tysiąclecia: „Zadrżyjcie i nie grzeszcie”.

8 Por. Mt 21,12-13; Mk 11,15-17; Łk 19,45-46; J 2,14-17. 
tych, którzy z powodu swojego postępowania zasłużyli na odrzucenie przez Boga i na poniesienie kary 9

Ojcowe Kościoła szybko zdali sobie sprawę, że muszą podjąć zagadnienie, którym zajmowała się już tradycja grecko-rzymska. Apateia, w której tradycja stoicka i epikurejska widziały rys wyróżniający boskości, okazała się wyjątkowo trudna do pogodzenia z obrazem Boga zagniewanego, który jest obecny na kartach Biblii. Za cenę wysiłków egzegetycznych, niekiedy dość dziwnych, najpierw Filon z Aleksandrii, a potem ojcowie: Hilary, Ambroży, Hieronim oraz Augustyn zdołali pozbawić gniew Boży sensu dosłownego, przenosząc go na poziom alegoryczny (moralny). W takiej interpretacji gniew Boży całkowicie różni się od gniewu ludzkiego - będąc manifestacją najwyższej sprawiedliwości Bożej, nie jest on niczym innym niż sprawiedliwym sądem, którego efektem jest kara, ale nie pociąga ona za sobą żadnego poruszenia emotywnego. Jawi się ludziom jako pasja, ale z pasji zachowuje tylko rysy zewnętrzne.

W tej tradycji egzegetycznej, która znalazła przedłużenie w teologii średniowiecznej, łącznie ze scholastyką, wyróżnia się stanowisko zaprezentowane przez Laktancjusza. Jego traktat De ira Dei, napisany na początku IV wieku, jest wyrazem reakcji przeciw pojęciu apatii Bożej właśnie w imię obrony wyjątkowości Boga chrześcijańskiego. Bóg, który nie gniewa się, jest - jak utrzymywali stoicy i epikurejczycy - Bogiem, który nie doświadcza żadnej pasji, jest niezdolny do miłowania i do zatroszczenia się o świat. Gniew Boga chrześcijańskiego jest ściśle związany z Jego miłością, a więc jest także pasją. Pasja ta jest w najwyższym stopniu dobra, ponieważ za jej pośrednictwem Bóg może ukazać swoją opatrzność i swoją sprawiedliwość. Laktancjusz pisze:

„Gdy więc [Bóg] ustanowił najświętsze prawo, i chce, by wszyscy byli niewinni i dobrze czyniący, czyż może się nie gniewać,

$9 \quad$ Por. Miggelbrink, Gniew Boży, passim. 
widząc prawo swe w pogardzie, cnotę w poniewierce i gonitwę za rozkoszą? A jeżeli jest rządcą świata, jak być powinien, przeto nie gardzi tym, co jest na wszelkim świecie bodaj największe. Jeśli jest przewidujący, jak przystało Bogu, w takim razie stara się o rodzaj ludzki, by życie nasze było zasobniejsze, lepsze i bezpieczniejsze. Jeżeli jest Ojcem i Bogiem wszystkiego, zapewne rozkoszuje się cnotami ludzi, a oburza się na występki; więc miłuje sprawiedliwych, a nienawidzi bezbożnych"10.

Taka koncepcja gniewu Bożego nie może nie mieć wpływu na stanowisko odnośnie do gniewu ludzkiego - gniew dopuszczony w stosunku do Boga nie może równocześnie prowadzić do pełnego i jednostronnego potępienia gniewu ludzkiego. Zresztą szczególna struktura fizjologiczna dana przez Boga człowiekowi, sytuująca żółć w wątrobie, pokazuje, że gniew ludzi jakoś łączy się z zamysłem Bożym. Doświadczenie poruszenia gniewu jest w pełni naturalne, tym natomiast, czego Bóg zabrania, jest trwanie w gniewie, przekształcanie poruszenia gniewliwego w nienaturalny stan nieustannego gniewu.

Wymóg zmierzenia się z tym nabrzmiałym tłem filozoficznym i teologicznym wpłynął stosunkowo szybko na zaliczenie gniewu do wad głównych. Dwuznaczność, którą odnotowały w stosunku do gniewu zarówno tradycja klasyczna, jak i tradycja chrześcijańska, nie przeszkodziły w uznaniu gniewu za wadę główną, ale na pewno wpłynęła na różnice w proponowanych ujęciach. Ewagriusz ${ }^{11}$ i św. Jan Kasjan, podobnie jak inni ojcowie greccy, na przykład Jan Klimak ${ }^{12}$, nie mają wątpliwości co do jednoznacznie grzesznej natury gniewu i jego głębokiej niespójności z życiem chrześcijańskim, zwłaszcza monastycznym. Ewagriusz widzi w gniewie wielką przeszkodę dla modlitwy i kontemplacji, wykluczając

10 Lactantius, De ira Dei, 19 (BOK 16, 193).

11 Evagrius Ponticus, Antirrheticus (Pisma ascetyczne, II, 195-201).

12 Por. Jan Klimak, Drabina raju, 176-180. 
zarazem, że mógłby istnieć jakiś „słuszny” gniew. Jan Kasjan widzi w gniewie bardzo niebezpieczną wadę, ponieważ często nie ujawnia się ona na zewnątrz, ale wnika w sam umysł i może go zniewolić, w związku z czym jest nad wyraz pewne, że nie ma żadnej racji dopuszczającej i uzasadniającej gniew. Niezależnie od tego, czy motyw jest słuszny czy też nie, reagowanie gniewem nigdy nie jest uzasadnione i powoduje zaciągniecie winy ${ }^{13}$.

Także św. Grzegorz Wielki nie ma żadnej wątpliwości co do konieczności włączenia gniewu do wad głównych: Ira jest córką zazdrości i matką smutku, gniew zagraża równocześnie wewnętrznej harmonii duszy oraz trwałości życia społecznego. Burząc podobieństwo człowieka do Boga, sprawia, że człowiek traci mądrość, życie, prawdę. Gniew oddala od sprawiedliwości, burzy zgodę i zamyka myśl na oświecenie ze strony Ducha Świętego: „Gdy gniew zarzuca na umysł ciemności wzburzenia, wtedy Bóg ukrywa przed nim promień Jego poznania. Gniew zamyka nas na blask Ducha Świętego" ${ }^{14}$. Wskazując na te wszystkie destrukcyjne skutki gniewu, św. Grzegorz wprowadza jednak bardzo zasadnicze rozróżnienie: „Czym innym jest gniew, który rodzi się z niecierpliwości, a czym innym ten, który pochodzi z gorliwości. Tamten rodzi się z wady, ten z cnoty"15. Istnieje więc forma gniewu będąca bezpośrednią konsekwencją miłości bliźniego i stanowiąca nieuchronną reakcję na winy, zarówno nasze, jak i innych. Oczywiście Grzegorz wie dobrze, że także gniew rodzący się z gorliwości szkodzi w jakiś sposób „oku umysłu" i oddala go od spokoju kontemplacji, ale chwilowe zaciemnienie nie jest niczym innym niż dobroczynnym poruszeniem, które, gdy zostanie opanowane, pozwala potem osiągnąć ogląd jeszcze przejrzystszy i bardziej świetlany niż poprzednio: „Właśnie dzięki temu, przez co [umysł] został

\footnotetext{
13 Ioannes Cassianus, Institutiones coenobiticae, 8, 5 (SCh 109, 345).

14 Gregorius Magnus, Moralia, 5, 45, 78 (ŹM 39, I, 451).

15 Gregorius Magnus, Moralia, 5, 45, 82 (ŹM 39, I, 455).
} 
tak zraniony, że przez jakiś czas nie mógł widzieć, zostaje w subtelny sposób doprowadzony do rzeczy wzniosłych"16. Metafora oka umysłu pozwala Grzegorzowi precyzyjnie określić okoliczności gniewu „słusznego”: może on być tylko chwilowy i opanowany, a przede wszystkim musi być podporządkowany rozumowi, którego polecenia wykonuje jak sługa. Pod takimi warunkami gniew stanowi ważne narzędzie walki z grzechem.

Klasyfikacje zaproponowane przez Jana Kasjana i Grzegorza Wielkiego, które stanowią wstęp do średniowiecznych analiz wad głównych, wyznaczają kluczowy moment w spojrzeniu na gniew. $Z$ aktu postawienia go na czele siedmiu wad głównych, po poważnej debacie, która temu posłużyła, stanowisko zajęte wobec gniewu zostało poddane weryfikacji, która zaowocowała bardziej zrównoważonym ujęciem. Wciąż uznawany on będzie za wadę prowadzącą do grzechu, wadę główną, która pozostaje aktualna do dnia dzisiejszego ${ }^{17}$, ale jednocześnie za wadę otwartą na pewne wyróżniające dopowiedzenia, których potrzebuje zarówno etyka, jak i doktryna chrześcijańska.

\section{Ujęcie św. Tomasza z Akwinu}

Na tym tle staje się zrozumiałe, jak wyraźnie nowatorskie jest postawione przez św. Tomasza z Akwinu w Sumie teologii pytanie: „czy gniew może być godziwy?”" ${ }^{18}$. Już w wielkiej pracy na temat zła De malo ${ }^{19}$, która opierała się na schemacie wad głównych wypracowanym przez św. Grzegorza Wielkiego, Akwinata otwarł nowy rozdział w refleksji nad gniewem, zadając pytanie: „czy każdy gniew jest zły, czy też jest jakiś

16 Gregorius Magnus, Moralia, 5, 45, 82 (ŹM 39, I, 456).

17 Por. Królikowski, Saligia, 71-80.

18 Thomas de Aquino, Summa theologica, II-II, q. 158, a. 1.

19 Na temat koncepcji zła i wad głównych Akwinaty, por. Mróz, Tajemnica, passim. 
gniew dobry?"20. W ujęciu św. Tomasza uderza nowe postawienie zagadnienia $\mathrm{w}$ stosunku do tradycyjnego schematu, który przez wieki kazał patrzeć na gniew niemal wyłącznie jako na wadę główną. Oczywiście odniesienie do gniewu-gorliwości zawsze towarzyszyło analizom gniewu-wady, ale faktycznie ograniczało się ono do szybkiego przywołania przytoczonej wyżej wypowiedzi św. Grzegorza traktowanej jako wypowiedź autorytatywna, ale nie stała się ona stwierdzeniem głębiej rozumianym, szerzej uzasadnionym i mającym określone konsekwencje.

Pytanie postawione przez Akwinatę wyrasta oczywiście z szerszego kontekstu teologicznego, który wyraźnie odzwierciedlił się w podejmowaniu zagadnień moralnych. W XIII wieku uległ zmianie klimat intelektualny i do pierwszych sum teologii układ materii moralnej zaczął być opracowywany w wyraźnie odmiennym kluczu, na co wpłynęło szersze niż w epokach patrystycznej i wczesnośredniowiecznej uwzględnianie „psychologii”. Wilhelm z Auxerre (zm. 1231 r.) wprowadził do swoich poszukiwań pytanie: „czy czyste i proste rozgniewanie się jest złem?"21. Jan z La Rochelle (ur. po 1190, zm. 1245) zdecydował się w swoim wykładzie mówić najpierw o gniewie-gorliwości, a dopiero później przeszedł do analizy gniewu-wady. Pierwszorzędne pozostaje jednak pytanie: czym jest gniew? Pytanie o to, czym jest gniew i czy jest wadą lub grzechem, jest przedmiotem analizy w ważnym i wpływowym średniowiecznym dziele, którym jest Summa fratris Alexandri ${ }^{22}$.

Podjęcie opracowanego przez św. Grzegorza ujęcia gniewu dobrego przeciwnego w stosunku do gniewu złego jawi się w tekstach scholastycznych jako podstawa do wszelkich dyskusji na temat tej wady. Nie chodzi o proste odwrócenie porządku dyskursu, ale o odnowione postawienie problemu

\footnotetext{
20 Thomas de Aquino, De malo, q. 12, a. 1.

21 Guillelmus Altissiodorensis, Summa aurea, 12, 8, q. 1 (II, 441-443).

22 Aleksander z Halles, Summa theologica (III, 537-538).
} 
gniewu w oparciu o całkowicie odmienne założenia. Wstępne podjęcie podwójnej natury gniewu i dyskusja o jego możliwej godziwości nie oznacza uznania za oczywiste tego, co zawsze stanowiło założenie refleksji średniowiecznej, a mianowicie że gniew jest istotnie i pierwszorzędnie wadą główną. Scholastycy w swoich analizach szukają odpowiedzi na pytanie: czy gniew jest wadą? Adekwatna odpowiedź jest możliwa tylko po udzieleniu odpowiedzi na bardziej pierwotne pytanie: czym rzeczywiście jest gniew?

Odpowiedź, która się wyłania, jest bardzo ścisła: gniew jest pasją, w związku z czym analiza gniewu-wady domaga się uprzedniej analizy gniewu-pasji. Zwrócenie się do kategorii pasji, przez długi czas zapomnianej w kulturze średniowiecznej, pozwoliło scholastykom przekroczyć aporie wynikające $\mathrm{z}$ nieco jednostronnego i powierzchownego spojrzenia na gniew jako wadę główną, a zarazem dokonać spójnej syntezy wszystkich tematów, które tradycyjnie łączono z zagadnieniem gniewu. Mówienie o gniewie-pasji oznacza jednak także zmierzenie się z autorytatywną tradycją grecką, która pasjom poświęciła wiele uwagi, oraz podjęcie na nowo debaty między stanowiskiem „perypatetyckim”, odkrytym w tekstach Arystotelesa, oraz stale żywą tradycją stoicką, która dzięki tekstom Seneki i Cycerona zawsze wywierała wpływ na kulturę średniowieczną. Św. Tomasz nie miał wątpliwości, za którym stanowiskiem się opowiedzieć stwierdzenia Arystotelesowskie, dystansujące się w stosunku do wypowiedzi św. Augustyna, stanowią punkt wyjścia dla wszystkich refleksji nad pasjami. „Neutralna” natura pasji, wyraźnie stwierdzona na kartach Etyki nikomachejskiej23, pozwala Tomaszowi z Akwinu wyodrębnić w ruchu pasjonalnym wspólny element gniewu-gorliwości i gniewu-wady, nie podlegający żadnej ocenie moralnej. Chodzi więc o wyjaśnienie, jakie w każdym przypadku są te elementy, które

23 Por. Aristoteles, De Ethica Nicomachea, 2, 5 (Arystoteles, Dzieta wszystkie, V, 110-113). 
przekształcają pasję, samą w sobie obojętną z punktu widzenia etycznego, w wadę gniewliwości lub w cnotę gorliwości.

Gniew, jako pasja zakorzeniona w sferze zmysłowej człowieka, jest pewnym poruszeniem naturalnym, które może przekształcić się w grzech z dwóch racji: jej przedmiotu i jej intensywności. Jeśli więc istnieją pasje, na przykład zazdrość, których przedmiot jest wewnętrznie zły, to można to samo powiedzieć na temat gniewu. Gniew, zgodnie z definicją sformułowaną przez Arystotelesa i przez Cycerona, i jednogłośnie przyjętą w nurcie scholastycznym, nie jest niczym innym niż pragnieniem zemsty, a zemsta jest częścią sprawiedliwości. Alternatywa między dobrem i złem przesuwa się w ten sposób z gniewu na zemstę, przedmiot, który w sobie jest dwuznaczny, gdyż składa się z dwóch elementów: przywrócenia naruszonej sprawiedliwości, które jest jednoznacznie dobre, oraz ukarania przestępcy, które obiektywnie jest złem. Nacisk położony na jeden bądź drugi z tych elementów wyznacza alternatywę moralną, w ramach której sytuuje się gniew. Gniew na pierwszym miejscu zwraca się przeciw osobie i zmierza zasadniczo do tego, aby została ukarana i poniżona, a to jest uczucie naznaczone winą, naruszające tę więź miłości, która powinna zajmować pierwsze miejsce wśród ludzi - jest więc grzechem. Co więcej, jest jedną z wad głównych. Gniew natomiast, który zw raca się przeciw winie, ma na celu wyłącznie przywrócenie sprawiedliwości i jako taki jest postawą cnotliwą.

Naturę pasji determinuje zarazem także jej intensywność, a refleksje na temat gniewu zawsze uwypuklały w „nadmiarze" jedną ze szczególnych cech tej pasji. W wykładach moralnych, począwszy od stoików, brak umiaru w gniewie był odczytywany jako znak zaciemnienia rozumu, w którym nadmierne manifestacje cielesne wady dostarczały potwierdzenia całkowitego zdominowania człowieczeństwa człowieka przez jego naturę zwierzęcą. W refleksji tomistycznej złożona „gra” rozgrywająca się między racjonalnością, pasyjnością i zwierzęcością wydaje się znajdować adekwatną równowagę, w ramach której można jeszcze raz odróżnić drogi cnoty od 
dróg wady. Oczywiście gniew, podobnie jak wszystkie pasje, obejmuje duszę i ciało bądź też, mówiąc lepiej, rodzi się on z tej nierozerwalnej złożoności duszy i ciała, którą stanowi człowiek. Nie zaskakuje więc, gdy manifestuje się ona na zewnątrz za pośrednictwem wyraźnie widocznych znaków. $\mathrm{Z}$ definicji zakłada ona bardzo głębokie zmiany fizjologiczne, jeżeli jest prawdą, że - jak zgodnie przyznają filozofowie i lekarze - pragnienie zemsty wyraża się we wzburzeniu krwi wokól serca, będącym pierwszorzędną przyczyną wszystkich efektów i zmian fizjologicznych, na co stale zwracano uwage w przeszłości. Właśnie szczególna natura pasji gniewu - wyjaśnia Akwinata - czyni ją tak bardzo „widzialną”. Pasja jest wewnętrznie sprzeczna, łącząc ze sobą dobro i zło, pragnienie i ucieczkę, manifestuje się także za pośrednictwem sprzecznych znaków - człowiek gniewliwy wpada w gadulstwo lub całkowicie milknie, porusza nerwowo wszystkimi członkami lub zastyga w kompletnym bezruchu.

Także bardziej widoczne aspekty gniewu nie powinny być odczytywane po prostu jako znak degradacji zwierzęcej lub triumfu irracjonalności. Jeszcze raz powraca kwestia porządku i umiaru: racjonalność i zdolność do pasji są istotnymi komponentami człowieka, ale rozum musi narzucić swoje reguły niższym sferom duszy. Co więcej, musi w jakiś sposób sprawić, aby ruchy pasjonalne mu służyły. Św. Grzegorz sugerował, że rozum powinien używać gniewu jak pan posługuje się sługą. Akwinata upatruje rys wyróżniający gniewu-cnoty w stosunku do gniewu-wady w uprzedniej roli rozumu w stosunku do pasji, tak że tylko po tym, jak rozum osądził i określił sposób zemsty, pasja może przejść do jego realizacji. Tradycyjny zarzut pod adresem gniewu, że powoduje zaciemnienie rozumu, jawi się jako znaczący tylko w stosunku do gniewu jako wady, ale zmienia swoją wymowę, gdy relacje między gniewem i rozumem zostają odwrócone i gniew staje się logiczną konkluzją czegoś w rodzaju sylogizmu praktycznego, którego oparciem jest uznanie przez rozum konieczności zemsty. 


\section{ZAKOŃCZENIE: „ŚWIĘTY GNIEW”}

Gdy nastąpi przywrócenie poprawnej i otwartej relacji podporządkowania pasji rozumowi, gniew nie musi być już traktowany jako „choroba duszy”, ale jawi się, przynajmniej w pewnym zakresie, jako pomoc, która pozwala urzeczywistniać to, co podpowiada rozum, a tym samym służy także kształtowaniu życia cnotliwego. Gniew jawi się jako blisko związany z gorliwością i służy jej jako źródło duchowego zapału. W tych ramach, które stanowią spójną kontestację stanowiska stoickiego, nie można już oddzielać pragnienia zemsty od jego manifestacji zewnętrznych, jakby dobre użycie pasji zakładało tylko systematyczne i zdeterminowane eliminowanie jej aspektów cielesnych. Realizacja sprawiedliwości nie dokonuje się na drodze odrzucenia ciała, ale domaga się jego współpracy, a dążenie do słusznej zemsty angażuje całego człowieka, jego część zmysłową i jego ciało. Spójne uwzględnianie pasji w doświadczeniu duchowym jawi się jako postulat antropologii integralnej, która uwzględnia, że człowiek w każdym czynie wyraża się jako jedność cielesno-duchowa.

Rozróżnienie w tym miejscu między gniewem-wadą i gniewem-cnotą jest - przynajmniej teoretycznie - bardzo łatwe. Jeśli zemsta zwraca się rzeczywiście przeciw temu, kto na nią zasłużył, w mierze odpowiedniej do zaistniałej „przyczyny”, przy poszanowaniu należnych form prawnych i mając na względzie słuszny cel, którym jest odbudowanie sprawiedliwości, i jeśli poruszenie gniewu nie przekracza słusznej miary, ani wewnętrznie, ani zewnętrznie, wówczas gniew jest jak najbardziej odpowiedni, jest cnotą i przybiera miano gniewu-gorliwości. Jeśli natomiast zemsta jest nieuzasadniona, to znaczy nie uwzględnia i nie respektuje wspomnianych zasad, jeśli jest motywowana tylko pragnieniem ukarania przestępcy bądź też wywołuje nadmierne perturbacje wewnętrzne lub zewnętrzne, jest gniewem-wadą i przybiera miano gniewliwości. 
Podobny „demontaż” pasji pozwala także udzielić spójnej odpowiedzi na problem gniewu Bożego. Dla Boga, który nie ma ciała, pragnienie zemsty nie jest pasją, ale czystym aktem woli. Bóg może zatem faktycznie mścić się, nie doznając przy tym żadnego poruszenia gniewu, a każde odniesienie do gniewu Bożego powinno być rozumiane w sensie metaforycznym. Chrystus natomiast we wcieleniu przyjął naturę ludzką we wszystkich jej aspektach, a więc doświadczał także pasji związanych ze sferą popędliwości. Jego gniew był faktycznie pasją, ale pasją absolutnie „uporządkowaną", ponieważ w pełni i spójnie podporządkowaną rozumowi, stanowił doskonały przykład tego gniewu-gorliwości, który także w przypadku ludzi stanowi niejednokrotnie niezastąpioną potrzebę ${ }^{24}$.

\section{Bibliografia}

\section{Źródła}

Alexander Halensis, Summa theologica seu sic origine dicta „Summa fratris Alexandri" (Quaracchi: Collegio San Bonaventura 1930) III.

Aristoteles, De Ethica Nicomachea, [w:] Aristote, Éthique de Nicomaque (red.J. Voilquin) (Paris: Garnier 1950); tt. polskie: Arystoteles, Dzieta wszystkie (Etyka nikomachejska, Etyka wielka, Etyka eudemejska, O cnotach i wadach) (tt. D. Gromska - L. Regner - W. Wróblewski) (Warszawa: Wydawnictwo Naukowe PWN 1996) V, 77-300.

Evagrius Ponticus, Antirrbeticus (red. W. Frankenberg) (Abhandlungen der königlichen Gesellschaft der Wissenschaften zu Göttingen. Philologisch-historische Klasse Neue Folge XIII, 2; Berlin: Weidmannsche Buchhandlung 1912) 472-545; th. polskie: Pisma ascetyczne (tt. B. Spieralska - L. Nieścior)

24 Por. Tomasz z Akwinu, In III Sententiarum, d. 15, a. 2, q. 2. 
(ŹM 36; Kraków - Tyniec: Wydawnictwo Benedyktynów 2016) II, 149-221.

Gregorius Magnus, Moralia in Job (red. A. de Gaudemaris) (SCh 32bis; Paris: Cerf 1975); tt. polskie: Grzegorz Wielki, Moralia. Komentarz do Ksiegi Hioba (tł. T. Fabiszak - A. Strzelecka - R. Wójcik) (ŹM 39; Kraków - Tyniec: Wydawnictwo Benedyktynów 2006) I.

Ioannes Cassianus, Institutiones coenobiticae (red. J.-C. Guy) (SCh 109; Paris: Cerf 1965).

Ioannes Climacus, Scala Paradisi (red. P. Trevisan) (Corona

Partrum Salesiana, Series Graeca, 8-9; Torino: SEI 1941);

tł. polskie: Jan Klimak, Drabina raju (tł. W. Polanowski)

(Kęty: Wydawnictwo Marek Derewicki 2011).

Lactantius, De ira Dei (red. Ch. Ingremeau) (SCh 289; Paris: Cerf

1982); tł. polskie: Laktancjusz, Pisma wybrane (tł. J. Czuj) (BOK 16; Poznań: Jan Jachowski, Biblioteka Uniwersytecka 1933) $161-207$.

Martinus Bracarensis, De ira (red. P. Farmhouse Alberto) [w:] Mediaevalia. Textos e estudios 4 (1993) 144-165.

Seneca, De ira, [w:] Seneca, I dialohi (red. N. Sacerdoti) (Milano:

Istituto Editoriale Italiano 1968) I, 117-335; tł. polskie: Seneka,

Pisma filozoficzne (tł. L. Joachimowicz) (Warszawa: Instytut Wydawniczy Pax 1965) I, 244-424.

Thomas de Aquino, Commentum in III Sententiarum (Parma:

Typis Petri Fiaccadori 1858) II.

Thomas de Aquino, Summa theologica (Paris: P. Lethielleux 1887) III. Thomas de Aquino, De malo [w:] Tommaso d'Aquino, Il male.

Testo latino a fronte (red. E. Fiorentino) (Milano: Rusconi 1999). Guillelmus Altissiodorensis, Summa aurea (red. J. Ribaillier) (Paris: CNRS - Grottaferrata: Collegio San Bonawentura 1984) II.

\section{Opracowania}

Cazelles H., La Bible et son Dieu (Paris: Desclée 1989).

Miggelbrink R., Gniew Boży. Znaczenie pewnej gorszacej tradycji biblijnej (tł. A. Wałęcki) (Kraków: Wydawnictwo WAM 2005). 
Królikowski J., Saligia. Wady gtówne wciąz aktualne (Kraków: Wydawnictwo Dehon 2017).

Leon-Dufour X., „Gniew”, Stownik teologii biblijnej (red. X. Léon-

Dufour; tł. i oprac. K. Romaniuk) (Poznań - Warszawa: Pallottinum 1985) 286-293.

Mróz M., Tajemnica ludzkiej nieprawości. Aktualność nauki św. Tomasza z Akwinu o ztu moralnym i wadach gtównych (Toruń: Wydawnictwo Uniwersytetu Mikołaja Kopernika 2010).

Veghetti M., „Passioni antiche: l'io collerico”, Storia delle passioni (a cura di S. Veghetti Finzi) (Roma - Bari: Laterza 1995) 39-73.

Ks. JanUSZ KRólikowsKi, prezbiter diecezji tarnowskiej, doktor habilitowany w zakresie teologii dogmatycznej, profesor Uniwersytetu Papieskiego Jana Pawła II w Krakowie, kierownik Katedry Teologii Dogmatycznej oraz dziekan Wydziału Teologicznego, Sekcja w Tarnowie, Uniwersytetu Papieskiego Jana Pawła II w Krakowie. 